\title{
Aquaculture Site Selection of Oncorhynchus Mykiss (Rainbow Trout) in Markazi Province Using GIS-Based MCDM
}

\author{
Amir H. Aghmashhadi ${ }^{1,2}$, Ali Azizi ${ }^{3}$, Maryam Hoseinkhani ${ }^{2}$, Samaneh Zahedi ${ }^{4}$ and Giuseppe T. Cirella ${ }^{5, *(\mathbb{D})}$ \\ 1 Department of Sustainable Landscape Development, Institute of Geosciences and Geography, Martin Luther \\ University Halle-Wittenberg, German Centre for Integrative Biodiversity Research Halle-Jena-Leipzig, \\ 06120 Halle, Germany; a-hedayati@araku.ac.ir \\ 2 Department of Environmental Science and Engineering, Faculty of Agriculture and Environment, \\ Arak University, Arak 38156879, Iran; mrm.hkhani72@gmail.com \\ 3 National Population Studies and Comprehensive Management Institute, Tehran 1531635711, Iran; \\ aliazizi89@psri.ac.ir \\ 4 Department of Environmental Management, Islamic Azad University, Tehran Science and Research Branch, \\ Tehran 1477893855, Iran; issamaneh.zahedi@srbiau.ac.ir \\ 5 Faculty of Economics, University of Gdansk, 81-824 Sopot, Poland \\ * Correspondence: gt.cirella@ug.edu.pl; Tel.: +48-585231258
}

Citation: Aghmashhadi, A.H.; Azizi, A.; Hoseinkhani, M.; Zahedi, S.; Cirella, G.T. Aquaculture Site Selection of Oncorhynchus Mykiss (Rainbow Trout) in Markazi Province Using GIS-Based MCDM. ISPRS Int. J. Geo-Inf. 2022, 11, 157. https:// doi.org/10.3390/ijgi11030157

Academic Editor: Wolfgang Kainz

Received: 10 January 2022

Accepted: 20 February 2022

Published: 22 February 2022

Publisher's Note: MDPI stays neutral with regard to jurisdictional claims in published maps and institutional affiliations.

Copyright: (C) 2022 by the authors. Licensee MDPI, Basel, Switzerland. This article is an open access article distributed under the terms and conditions of the Creative Commons Attribution (CC BY) license (https:// creativecommons.org/licenses/by/ $4.0 /)$.

\begin{abstract}
The production of seafood, particularly in areas far from coastlines, makes aquaculture an optional farming alternative. Case research from the semi-arid Markazi province, Iran, is examined as a viable aquaculture location for Oncorhynchus mykiss (rainbow trout). ArcGIS Version 10.6.1 and Super Decision Version 3.2 software are utilized for the zoning and assessment of criteria maps. All criteria, i.e., sub-criteria and limitations, were gathered through the academic literature, qualitative interviews via expert opinion, national data, and guidelines. By imposing constraints on the premier aquatic potential map, the final map of the aquaculture potential of Markazi province was obtained. The results indicated that $40.79 \%$ of Markazi province has a high potential for aquaculture development. According to the sensitivity analysis, changes in criterion value (i.e., increase or decrease) in weight corresponded with the rate of change. Aquaculture development would require large-scale investment and make Markazi province a major seafood producer in the region.
\end{abstract}

Keywords: offshore aquaculture; multi-criteria; analytic network process; suitability mapping; semiarid area; Iran

\section{Introduction}

When taking into consideration the significant decline in marine fisheries catchments, aquaculture is believed to be a suitable substitution to globally supplying fish and seafood protein [1-3]. Aquaculture is one of the fastest-growing activities worldwide. The strong and rapid development of the sector tends to reflect significant environmental impacts and challenges [4]. Despite the immense potential of aquaculture for food and livelihoods, "new aquaculture initiatives are often dominated by donor-driven projects instead of local entrepreneurships" [5], which can be highly affected by aquaculture governance and production-related incentives. Nonetheless, aquaculture is one of the fastest-growing protein production systems, supplying approximately $47 \%$ of the world's protein demand [6]. Aquaculture activities have been significantly improved in recent years with a continued increase in its production targets. The socioeconomic gains obtained from aquaculture development provide nutritive food, improve the lives of the impoverished, diversify fish production, generate capital and employment opportunities, and allow for high-value export earnings [7]. A key challenge for aquaculture development is the sharing of water, land, and other alternatives, such as agriculture and tourism. Spatial planning for aquaculture - including zoning, land evaluation, and the design of aquaculture management areas-should consider the balance between the environmental, social, economic, 
and governance objectives of local communities, in-line with sustainable development theory $[8,9]$ and the ecosystem system approach [10].

Site selection is the initial critical factor in beginning the "process, expansion, or relocation of businesses of all kinds" [11]. Land evaluation is a multifaceted practice. Scientifically, it is commonly resolved using utility theory, e.g., a simple linearity weighted method, analytic network process (ANP) method, and technique for order preference by similarity to an ideal solution [12]. Hence, several solutions and valuation criteria should be considered beforehand [13]. First, the location of aquaculture is very specific and must consider climate, establishment, and facilities needed [14]. Effective land evaluation can improve aquaculture efficiency and lower the environmental impact [15]. Geography-based software such as geographic information systems (GIS) [16] are frequently used for spatial planning (e.g., aquaculture), in which different sets of feasible and local-oriented evaluation criteria are designed and optimally identified-with alternative locations considered [17-19]. The ability to create territorial information strengthens the use of spatially-based analyses in combination with multi-criteria decision-making (MCDM) techniques [20-23]. Traditionally, land evaluation was centered on technical and economically oriented criteria; however, presently, more sophisticated methods are demanded. Selection criteria must take into account several environmental and social requisites that must be administered by legislative bodies and government regulations [24]. The implementation of GIS models can aid in resolving a number of these problems $[25,26]$. Selecting a location that is suitable can lower distribution costs, minimize environmental impacts, and reduce transport activities [27]. Various MCDM approaches have been utilized in the site selection of such facilities [28,29]. ANP, a MCDM ranking approach, is used to evaluate locations by using key decision criteria to reduce such costs and the associated negative effects. The development of a model that can identify the optimal locations for aquaculture facilities is designed on a hybrid GIS-based criteria approach that uses empirical findings from each criterion, i.e., by limiting uncertainty and simplifying a decision support system's approach, to obtain the suitability of a location [30]. The resulting models can be used to obtain ecological insight or predict distribution, with applications in spatial management, biosecurity, climate change, and theoretical ecology [31].

GIS, a digital database management system, is designed to manage large volumes of spatially distributed data from a multiplicity of sources [32]. These systems are ideal for land evaluation as they efficiently catalogue, retrieve, analyze, and exhibit applicationspecific data [33]. The practice of GIS modeling for the selection of marine aquaculture sites is commonly used, with varying socioeconomic, logistic, and environmental criteria [34-38]. Generated modelled maps-labeled with the descriptor classes (i.e., variables of interest), factor layers (i.e., converted descriptors), and constraint layers-are weighed and put through a multi-criteria analysis [39]. GIS site selection has been utilized throughout the literature for a variety of aquaculture applications, including hard clam culture in Florida [40], shrimp farming development in northwest Mexico [29], land suitability of aquaculture of rainbow trout in Peru [41], brackish site selection for water aquaculture in India [42], land-based shrimp farming along the Australian coast [43], shrimp farming in Vietnam [44], marine fish cages within the tourism industry in Tenerife [45], oyster culturebased single-use site selection in Venezuela [34], cage culture marine fish in Tenerife [46], and site selection of Japanese scallop in Japan [36,47], as well as assessing suitable carp farming areas, shrimp and crab farming, urban aquaculture development, tilapia farming areas, and modeling of land suitability for giant prawn in Bangladesh [48-50].

Recently, GIS integrated with MCDM was found to be a near best practice for aquaculture site selection and land evaluation [14,50-53]. In tangent, these methods improve the decision-making and planning processes [54]. A number of studies, specific to land evaluation and site selection, support MCDM approaches in the GIS environment [54-59]. This study presents a GIS-based MCDM that uses ANP to identify the most suitable places for aquaculture development in Markazi province, found geographically on the central plateau of Iran. Two study-specific points are important to this study, namely: (1) water 
quality in terms of aquaculture land evaluation in Iran is not an important factor as it is internally controlled and adjusted by the government prior to any site implementation, and (2) increasing land evaluation parameters can improve the accuracy of the location selection, e.g., by increasing layers and data. As such, when conducting land capability assessment that requires large-scale government investment to create or expand current facilities, as in Markazi province, the potential to develop aquaculture facilities in Iran is a top-down process. The most important and compatible type of edible farmed fish species in the province is Oncorhynchus mykiss (rainbow trout), which is classified as a cold-water fish and has been pilot bred with success in a few farming pools throughout Iran's central plateau area. A breakdown of the paper is structured as follows: Section 2 contains the methodology, Section 3 illustrates the results, and Section 4 elucidates a discussion and conclusion with suggestions for future research.

\section{Materials and Methods}

\subsection{Study Area}

Markazi province is found in central Iran (i.e., east of Zagros) and south of the capital (i.e., Tehran; Figure 1). Examination of long-term climate statistics in Markazi province indicates that, in general, the climate is dry and cold, with long-term average rainfall slightly higher than the national average at $281.5 \mathrm{~mm}$ [60]. The existence of a surface water network in conjunction with its centralized location and proximity to densely populated cities make the province relatively suitable for the growth and development of aquaculture. Examples of breeding ponds in Iran are divided into two categories: mechanized and traditional. In the case of Markazi province, small-scale traditional fishponds have been trialed using water construction (Figure 2) and using barriers (i.e., small dams) along rivers.

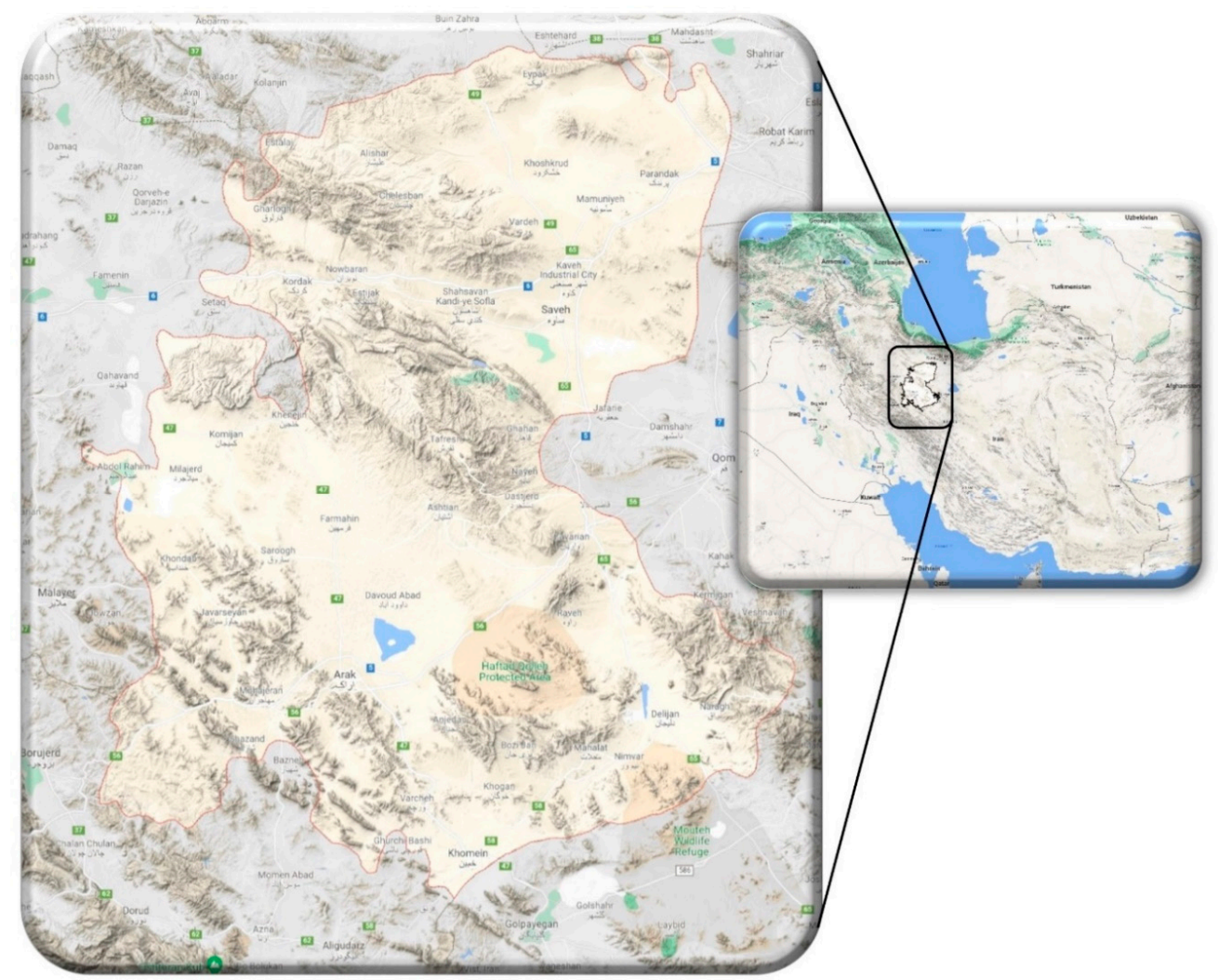

Figure 1. Geography and location of Markazi province in Iran; maps sourced from Google Earth [61]. 


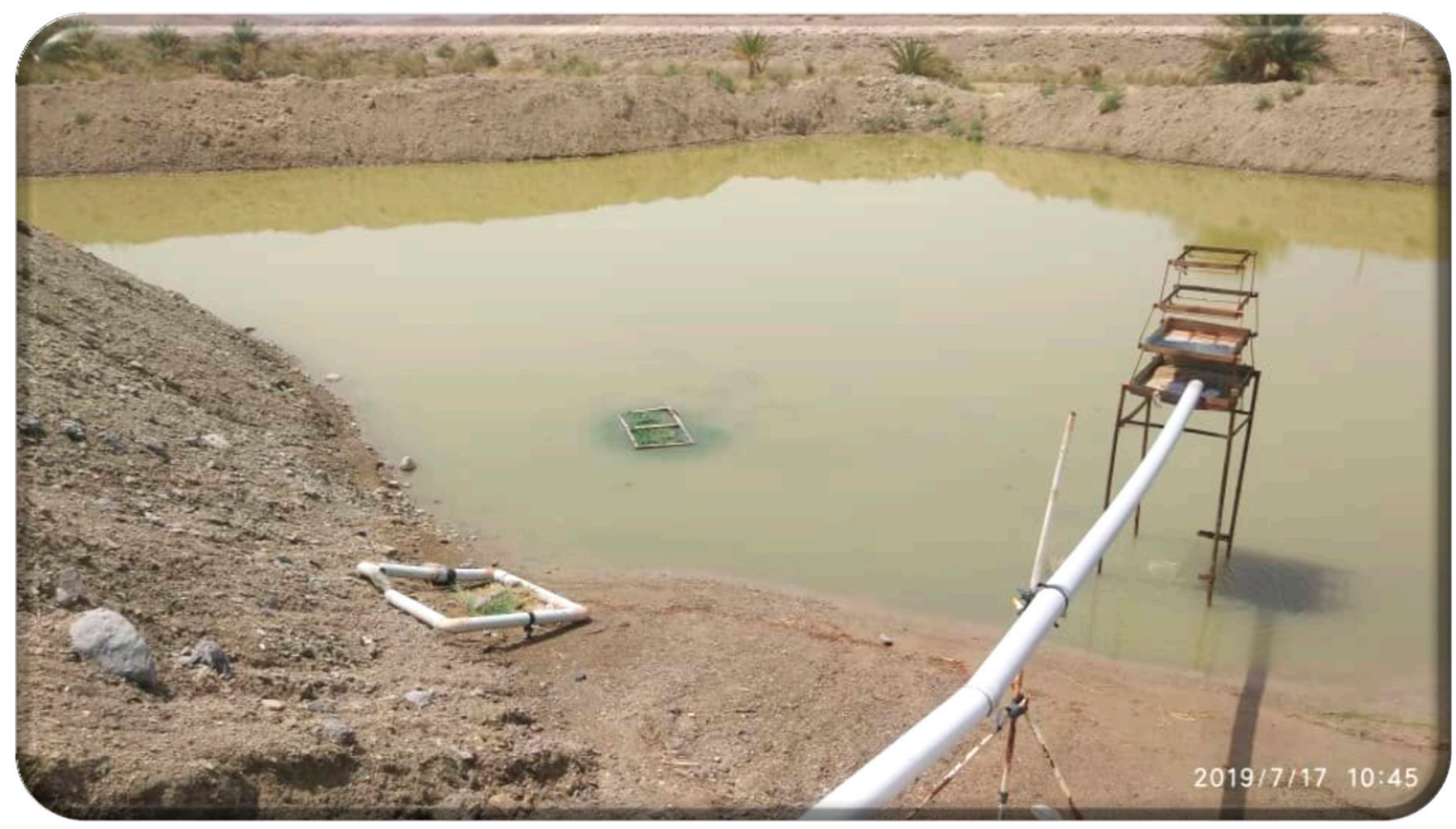

Figure 2. Example of traditional fish breeding pond in Markazi province. Photography taken by Amir H. Aghmashhadi on 17 July 2019.

\subsection{Methods}

This study uses a GIS-based MCDM to identify the suitability of sites for the development of aquaculture via ANP. The research comprises spatially oriented datasets and decision-making preferences, as well as their combination. The study combines the flexibility of GIS to appraise geographical information and determine whether MCDM can integrate the information properly. The premise of the research is to identify suitable sites and model output based on hybrid techniques of suitable options for integrated assessment in conjunction with correct decision-making when an area is selected for aquaculture development. The framing of the GIS-based MCDM uses six stages, namely, (1) identify decision criteria for the selected location based on guidelines by Makhdoum [62], (2) determine the criteria weighing using ANP-based responses from experts, (3) construct map layers for decision criteria using GIS analytical tools (i.e., to determine values for each grid in the study area), (4) perform land suitability analysis of the study area to generate a location suitability map and identify candidate sites, (5) remove the areas with constraints from the production map and classification of the final output map, and (6) sensitivity analysis (i.e., by using Super Decision Version 3.2 software). A robustness test was also utilized by using the fault injection testing method. This was performed to check the robustness by injecting faults (i.e., errors) in the software and observing the system's resilience [63]. We explored various contrasting randomization faults and found through a training simulation for the map outputs, convergence curve (i.e., threshold) was reached where the parameters provided one number for each parameter, instead of multiple numbers. The framework incorporates spatial-based evaluation modeling, societal aberrations and concerns, and local infrastructure (Figure 3). ArcGIS Version 10.6.1 software was used to create criteria mapping via the grid-based technique and weights were applied, using Equation (1), to each of the factors.

$$
\text { grid }_{\text {result(basic criteria-limitations) }}=\sum_{i=1}^{n}\left(\text { grid }_{i} * W_{i}\right)
$$

where $n=$ summation upper limit, $i=$ summation index, and $W=$ weight. 


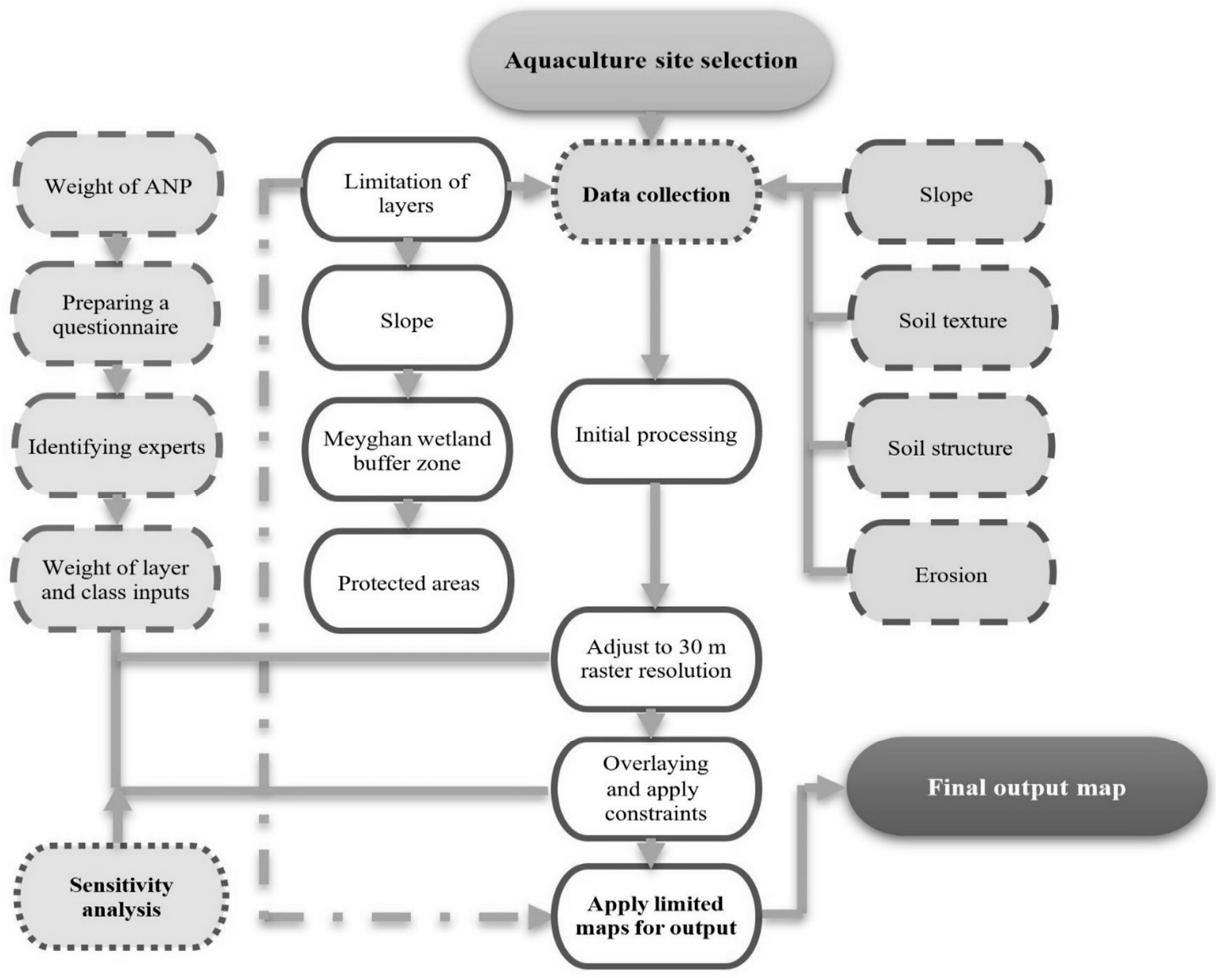

Figure 3. Methodology flowchart.

The ecological potential for aquaculture development in Markazi province was pieced together using datasets from different sources. Table 1 presents the raw list of data layer resources and references.

Table 1. Raw data in the study.

\begin{tabular}{|c|c|c|c|}
\hline Raw & Layer & Reference & Year of Dataset Layer \\
\hline 1 & $\begin{array}{l}\text { Political areas of the country } \\
\text { and province }\end{array}$ & Iran National Cartographic Center & 2016 \\
\hline 2 & Digital elevation model (DEM) & $\begin{array}{l}\text { DEM Shuttle Radar Topography Mission } \\
\text { with } 30 \text { m raster resolution }\end{array}$ & 2020 \\
\hline 3 & Slope & DEM data obtained from ArcGIS & 2020 \\
\hline 4 & Soil texture & $\begin{array}{l}\text { Office of Planning and Budget Organization, } \\
\text { Markazi province }\end{array}$ & 2009 \\
\hline 5 & Soil structure & $\begin{array}{l}\text { Office of Planning and Budget Organization, } \\
\text { Markazi province }\end{array}$ & 2009 \\
\hline 6 & Soil erosion layer & $\begin{array}{l}\text { Office of Agriculture Organization at Jahad, } \\
\text { Markazi province }\end{array}$ & 2012 \\
\hline 7 & $\begin{array}{c}\text { Wetland and environmentally } \\
\text { sensitive areas }\end{array}$ & $\begin{array}{c}\text { Department of Environment, } \\
\text { Markazi province }\end{array}$ & 2020 \\
\hline
\end{tabular}


After preparing the initial layers, i.e., in Table 1, the required processing was performed. Initially, the layers are divided by their political boundaries around the province's layer. Follow this, the coordinate system for the layers is interfaced with the World Geodetic System (i.e., WGS_1984_UTM_Zone_39N). Then, using ANP, the weight of each layer and their classes were obtained using the Super Decision Version 3.2 software environment. Within this structuring, three soil-related datasets (i.e., soil texture, soil structure, and erosion) were transformed into a raster format with a 30-m block size by assigning the weight obtained through ANP to their classes using the raster feature tool. Then, the slope layer was prepared from the province's DEM and classification (i.e., via the reclassify tool) and class weight were applied to it. The prepared criteria were overlaid by applying the weight of each, using the raster calculator tool in GIS software. Using the reclassify tool, it was classified into five categories, i.e., ranked from very low to very high suitability. Then the restriction layer was prepared and applied in the final map. To this end, the area of the classes was formulated using the calculate geometry tool. The layers are then integrated according to up-to-date datasets from Markazi province, and the according weights are allocated. Using GIS, the area of layer class is considered on its own. The data layers are overlaid to show the aquaculture-friendly area. Then, using the raster approach, the resource layers which allocate all primary data to raster layers of $30 \mathrm{~m}$ of resolution are assigned weight. Each layer's weight and associated class is determined using expert opinion in the form of ANP.

\subsection{Determining Criteria}

Suitable site selection and zoning is used to develop aquaculture areas using an MCDM process via a considered set of criteria. All the criteria were compiled by assessing the state of the art (i.e., the academic literature), qualitative interviews via expert opinion, local conditions of Markazi province, and Iran's national standards and laws [62]. The snowball procedure was utilized to find the experts for the study [64]. In the procedure of administering the qualitative interviews, 75 experts from Arak university-i.e., 15 experts, Islamic Azad University Arak Branch-i.e., 10 experts, and the province's fisheries establishments-i.e., 50 experts, participated in the study in October 2020.

\subsection{Analytical Process}

ANP is employed to define the weight of criteria via expert opinion as well as their importance in terms of decision criteria. ANP is a MCDM method that transforms the decision process into a decision criteria network [65]. Using this approach, the twopair comparison system aided in determining the weight of the structural conditions followed by the prioritization of the criteria in the MCDM process [12,15,64,66,67]. Many researchers have used ANP approaches in selecting locations and evaluating and analyzing land $[12,15,64,67-71]$. Steps for applying ANP are pieced together in four-step process. Details of the compiled data are available as Supplementary Tables S1-S5.

- Step 1. Show the significance and value of the factors based on the criteria. Utilize pairwise comparison to consider the impact of each element versus other elements. Conceptually, an example of the pairwise comparison used to evaluate the suitability of land in can be seen in Figure 4. 


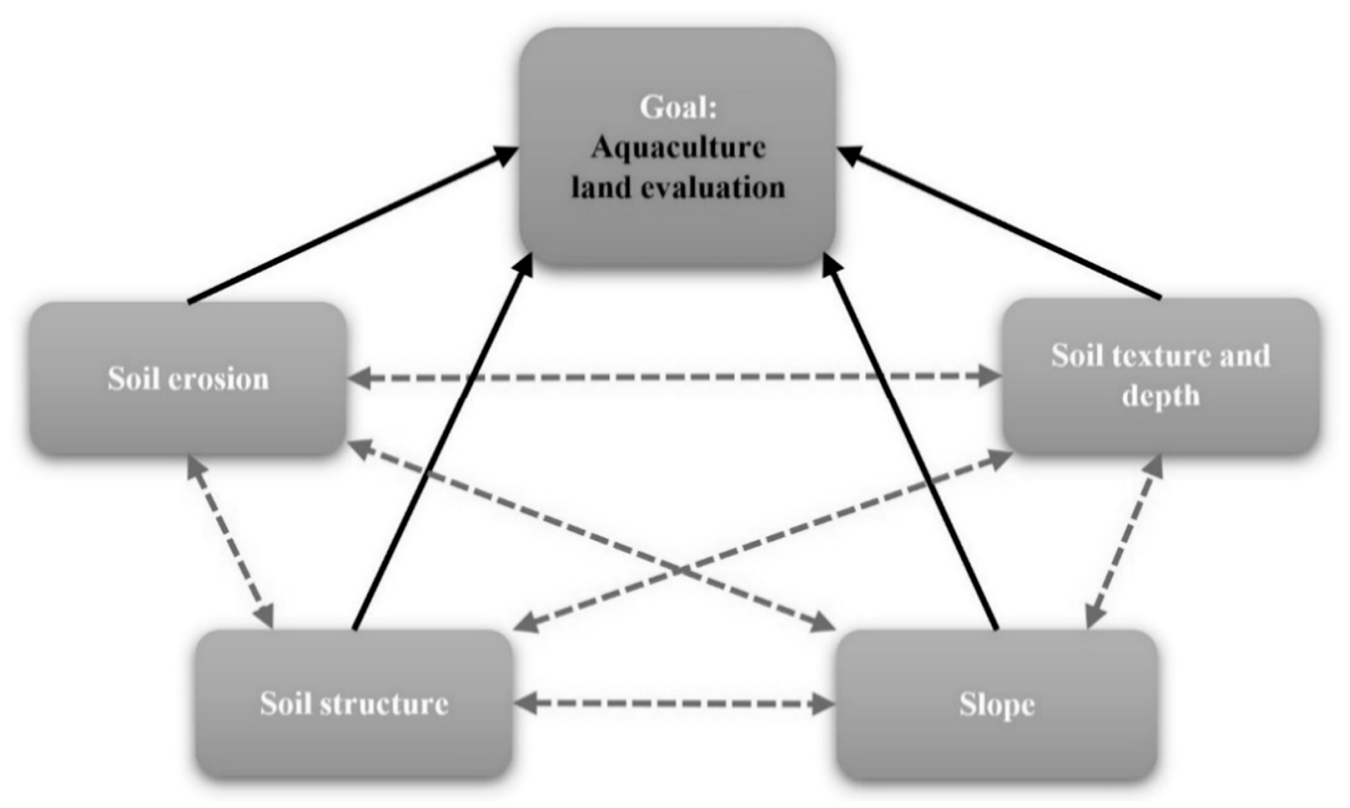

Figure 4. Conceptual model of aquaculture land evaluation in Markazi province.

- $\quad$ Step 2. Scale sub-factors of the elements. To compare elements in each cluster, scales in discrete intervals are chosen (i.e., 1-9 where scale 9 shows the absolute significance of an element in comparison with others and scale 1 shows the equal significance of the elements). Note the $a_{i j}$ indicates the importance of the $i^{\text {th }}$ element with respect to the $j^{\text {th }}$ element $[72,73]$.

- Step 3. Calculate the super matrix that is partitioned and based on the cluster (i.e., factors) and its elements (i.e., from the pairwise comparison). The super matrix, i.e., Equation (2), consists of $N$ clusters is presented as follows:

$$
\begin{aligned}
& \begin{array}{llllll}
C_{1} & \cdots & C_{k} & \ldots & C_{n}
\end{array}
\end{aligned}
$$

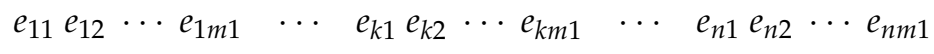

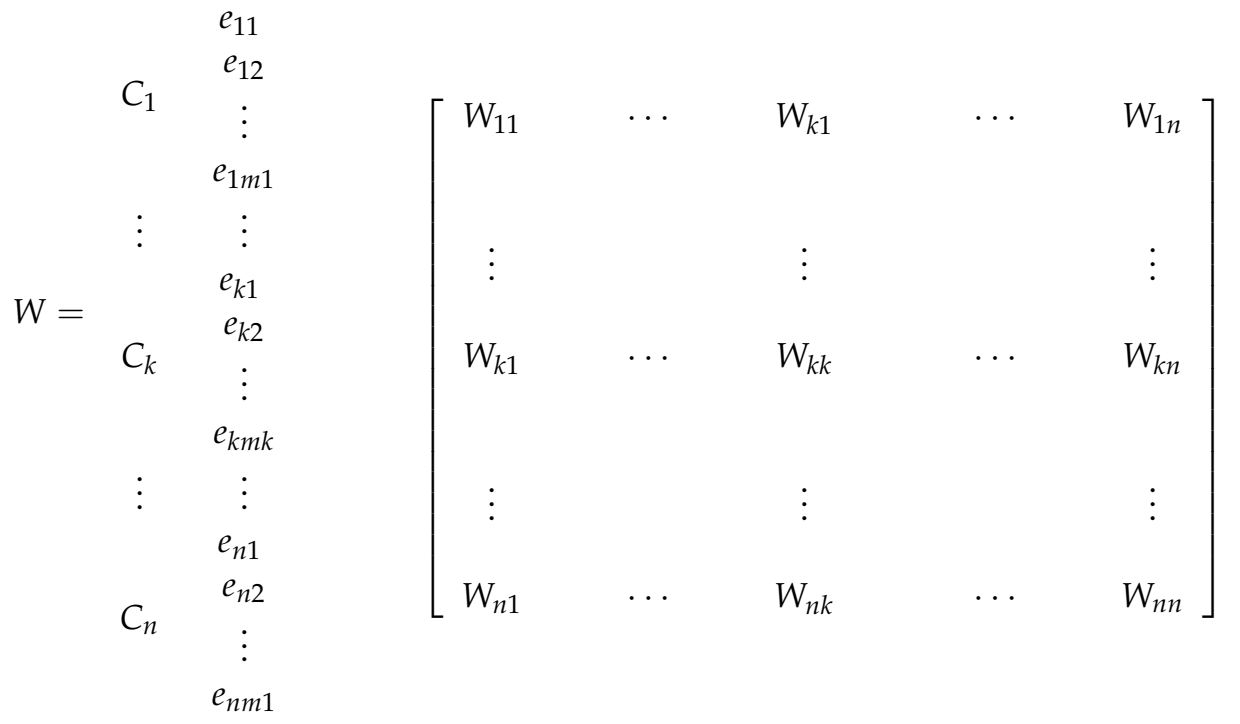

where: $C_{k}=$ the $k$ th cluster (i.e., $k=1,2, \ldots, n$ ) and each cluster $k$ consists of $m k$ items displayed by $e_{k 1}, e_{k 2}, \ldots, e_{k m k}$. Each column of $W_{i j}=$ the priority vector acquired from the identical pairwise comparison, indicating the significance of the elements in the $i^{\text {th }}$ cluster with respect to an element in the $j^{\text {th }}$ cluster. 
- Step 4. Compute the weight of the super matrix by multiplying the matrix by priority factors, creating a limited super matrix, and raising the weighted super matrix to the appropriate limit. The limited super matrix is obtained using Equation (3).

$$
\lim _{\varphi \rightarrow \infty}=\left(W^{a}\right)^{\varphi}
$$

where: $W^{a}=$ weighted super matrix, $a=$ element, and $\varphi=$ limit of the function.

After distributing the questionnaire among the experts, the results of their comparison and weighting are determined, by Super Decision Version 3.2 software. Among the effective criteria in the assessment of potential aquaculture facilities in Markazi province, slope is the most important criterion with a weight of 0.449 , followed by soil erosion with a weight of 0.265 , soil structure with a weight of 0.145 , and soil texture and depth with a weight of 0.141 . These weights are the aquaculture land capability (i.e., priority) criteria results for the study and are used to determine the development potential of aquaculture in the region. After determining the weight between the criteria, the weight of the classes of each criterion is determined.

A noteworthy point to this method is that to locate the aquaculture locations in the study area as accurately as possible, in addition to weighing the criteria in the location selection, the classes of each criterion are weighted according to the experts and prioritized accordingly. As such, the ANP method utilized determines the weight of the criteria according to expert opinion and their importance aids in determining decision criteria outputs. It is important to point out that the solving of problems, using a network that largely depends on modeling and network design, does not follow a certain rule. Therefore, problem solving has its complexity, of which, it is not possible to generalize an overall rule or formula to solve them [69]. ANP can be a very useful framework for analyzing development issues, as it can be used to study internal and external relations, mutual relations of elements and variables, application of quantitative and qualitative criteria, adaptability in judgments, the possibility of paired comparison of variables in decision making, the possibility of final prioritization of proposed options, and overcome the problems of hierarchical relationships from top to bottom or from bottom to top by ignoring the concept of feedback. This process is a flexible way of helping decision makers analyze complex issues whose elements are to be decided; altogether, it is a comprehensive and powerful way to make accurate decisions. The ANP model can also be combined with other models, e.g., the FANP model in combination with ANP and fuzzy in which language estimations are converted into fuzzy numbers-as suggested by Malmir et al. [65], Zarei et al. [69], Yunna et al. [71], and Seyedmohammadi et al. [66]. Finally, the Ethical Committee of University of Gdansk, in cooperation with Arak University, has verified that this study complies with the ethics of scientific research described in the Ethical Principles of the Declaration of Helsinki and other applicable ethical principles and legislation in the European Union conforming with Directive 2010/63/EU. 


\section{Results}

Using Makhdoum's [62] ecological land capability potential assessment model, the land area for aquaculture uses and natural conditions of the region are assessed using different classes of layers to establish via expert assigned weights (Table 2). The results illustrate that the classes with higher utility should receive a higher weight. For example, traditionally slope classes of up to $5 \%$ and above $65 \%$ have been of equal importance, while for this study slope classes weighted from $0-5 \%$ are more than 17 times the weight of a slope class above $65 \%$.

Table 2. Class and the associated weight of each layer in the aquaculture land evaluation of Markazi province.

\begin{tabular}{|c|c|c|c|c|c|c|c|c|c|c|c|}
\hline Raw & Layer & & & & & Propert & & & & & \\
\hline \multirow{2}{*}{1} & \multirow{2}{*}{ Slope (\%) } & Class & $0-5$ & $5-8$ & $8-12$ & $12-15$ & $15-20$ & $20-30$ & $30-50$ & $50-65$ & $>65$ \\
\hline & & Weight & 0.325 & 0.233 & 0.165 & 0.111 & 0.078 & 0.059 & 0.048 & 0.036 & 0.026 \\
\hline \multirow{2}{*}{2} & \multirow{2}{*}{$\begin{array}{l}\text { Soil } \\
\text { erosion }\end{array}$} & Class & Low & Medium & High & & & & & & \\
\hline & & Weight & 0.670 & 0.201 & 0.129 & & & & & & \\
\hline \multirow[t]{2}{*}{3} & \multirow[t]{2}{*}{$\begin{array}{c}\text { Soil } \\
\text { texture } \\
\text { and depth }\end{array}$} & Class & $\begin{array}{l}\text { Deep } \\
\text { loam } \\
\text { clay }\end{array}$ & $\begin{array}{l}\text { Semi-deep } \\
\text { sandy loam } \\
\text { clay }\end{array}$ & $\begin{array}{l}\text { Semi- } \\
\text { deep } \\
\text { clay } \\
\text { loam }\end{array}$ & $\begin{array}{l}\text { Deep } \\
\text { sandy }\end{array}$ & $\begin{array}{c}\text { Shallow } \\
\text { sandy }\end{array}$ & $\begin{array}{c}\text { Shallow } \\
\text { sandy } \\
\text { loam }\end{array}$ & $\begin{array}{l}\text { Semi- } \\
\text { deep } \\
\text { sandy } \\
\text { loam }\end{array}$ & $\begin{array}{l}\text { Semi- } \\
\text { deep } \\
\text { loam } \\
\text { clay }\end{array}$ & \\
\hline & & Weight & 0.331 & 0.231 & 0.156 & 0.106 & 0.071 & 0.048 & 0.033 & 0.024 & \\
\hline \multirow[t]{2}{*}{4} & \multirow[t]{2}{*}{$\begin{array}{c}\text { Soil } \\
\text { structure }\end{array}$} & Class & $\begin{array}{c}\text { Fine- } \\
\text { grained } \\
\text { sedi- } \\
\text { ment }\end{array}$ & $\begin{array}{l}\text { Semi- } \\
\text { transformed }\end{array}$ & $\begin{array}{l}\text { Flooded } \\
\text { soil }\end{array}$ & Frost soil & $\begin{array}{c}\text { Flat and } \\
\text { calcare- } \\
\text { ous }\end{array}$ & $\begin{array}{l}\text { Low- } \\
\text { transforme }\end{array}$ & $\begin{array}{l}\text { Without } \\
\text { evolu- } \\
\text { tion and } \\
\text { rocky }\end{array}$ & $\begin{array}{l}\text { Without } \\
\text { evolu- } \\
\text { tion and } \\
\text { coarse } \\
\text { texture }\end{array}$ & $\begin{array}{l}\text { Often } \\
\text { salty }\end{array}$ \\
\hline & & Weight & 0.313 & 0.223 & 0.152 & 0.108 & 0.074 & 0.051 & 0.036 & 0.025 & 0.018 \\
\hline
\end{tabular}

After establishing criteria weight and criteria classes and applying them, removal of the constraints (i.e., controls) (Table 3 and Figure 5) from the base maps was performed (Figure 6). The limitation factors of slope (\%), protected area, and Meyghan Wetland buffer zone (presented in Figure 5) were combined to make-up the limitation map and were integrated into the data collection process as illustrated in the methodology framework. As a final finding, the modeled maps were all overlaid on each other to illustrate a final map of suitable places aquaculture development could be done in Markazi province (Figure 7).

Table 3. Imposed limitation of land use for aquaculture.

\begin{tabular}{ccc}
\hline Raw & Layer & Limitation \\
\hline 1 & Slope (\%), Makhdoum (2015) & 15 \\
2 & Protected area, Makhdoum (2015) & Protected area \\
3 & Meyghan Wetland buffer zone (m), Department of Environment [74] & 1500 \\
\hline
\end{tabular}



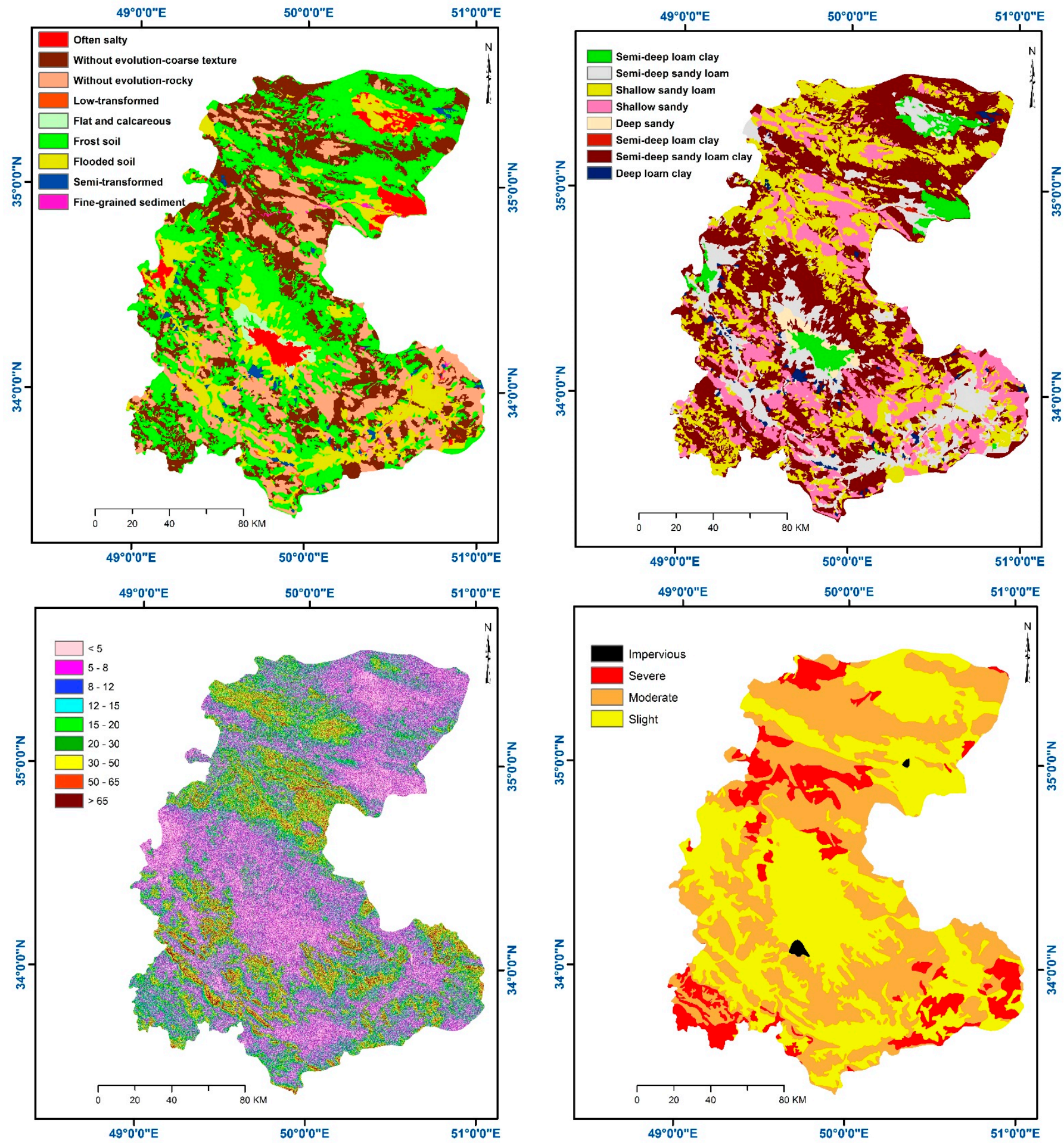

Figure 5. Classification map of each criterion: soil structure-top left; soil texture and depth-top right; slope (\%)—bottom left; soil erosion—bottom right. 


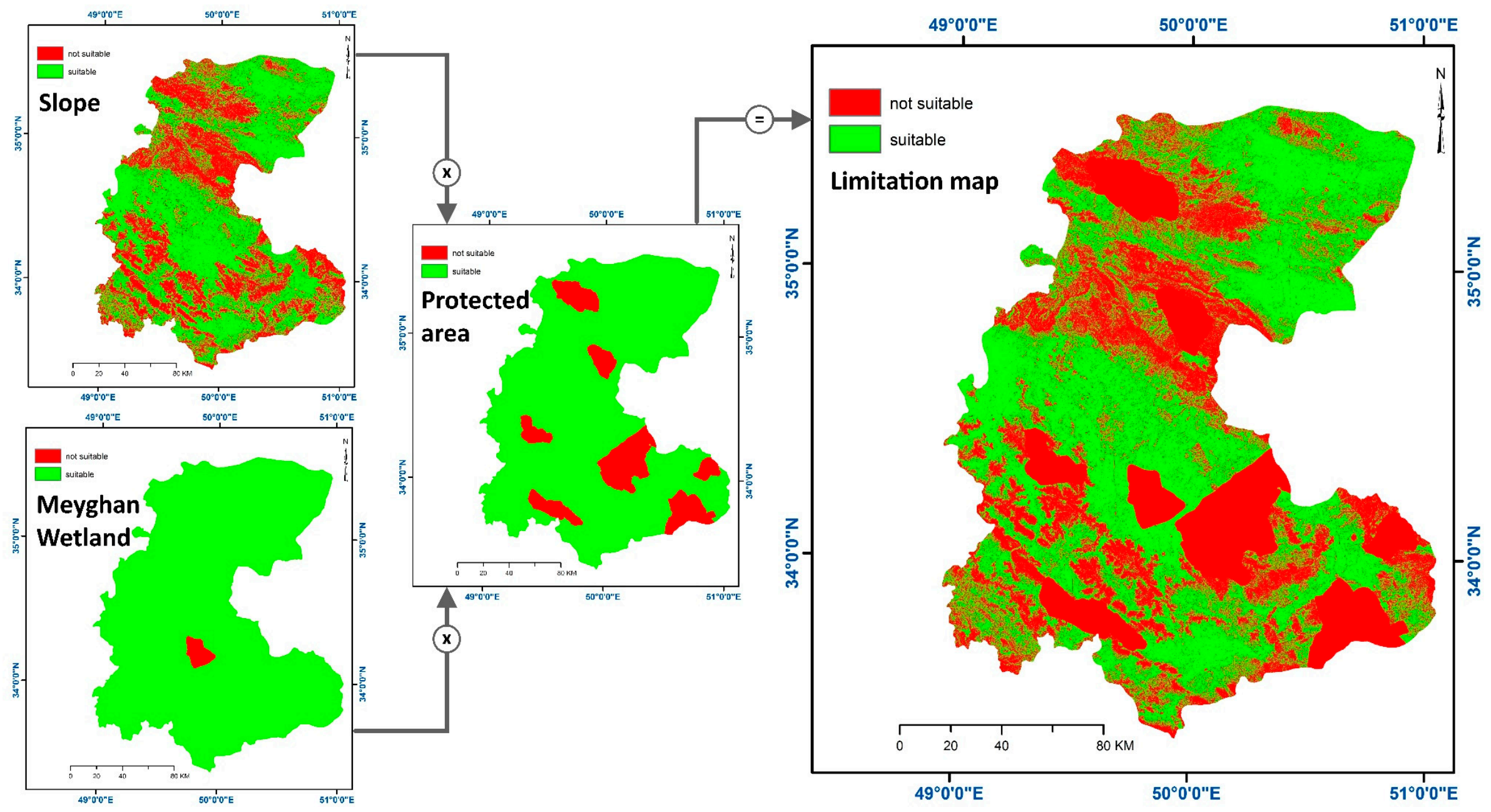

Figure 6. Restriction maps used to determine aquaculture land use in Markazi province: slope (\%), protected area, Meyghan Wetland buffer zone, and combined limitation map. 


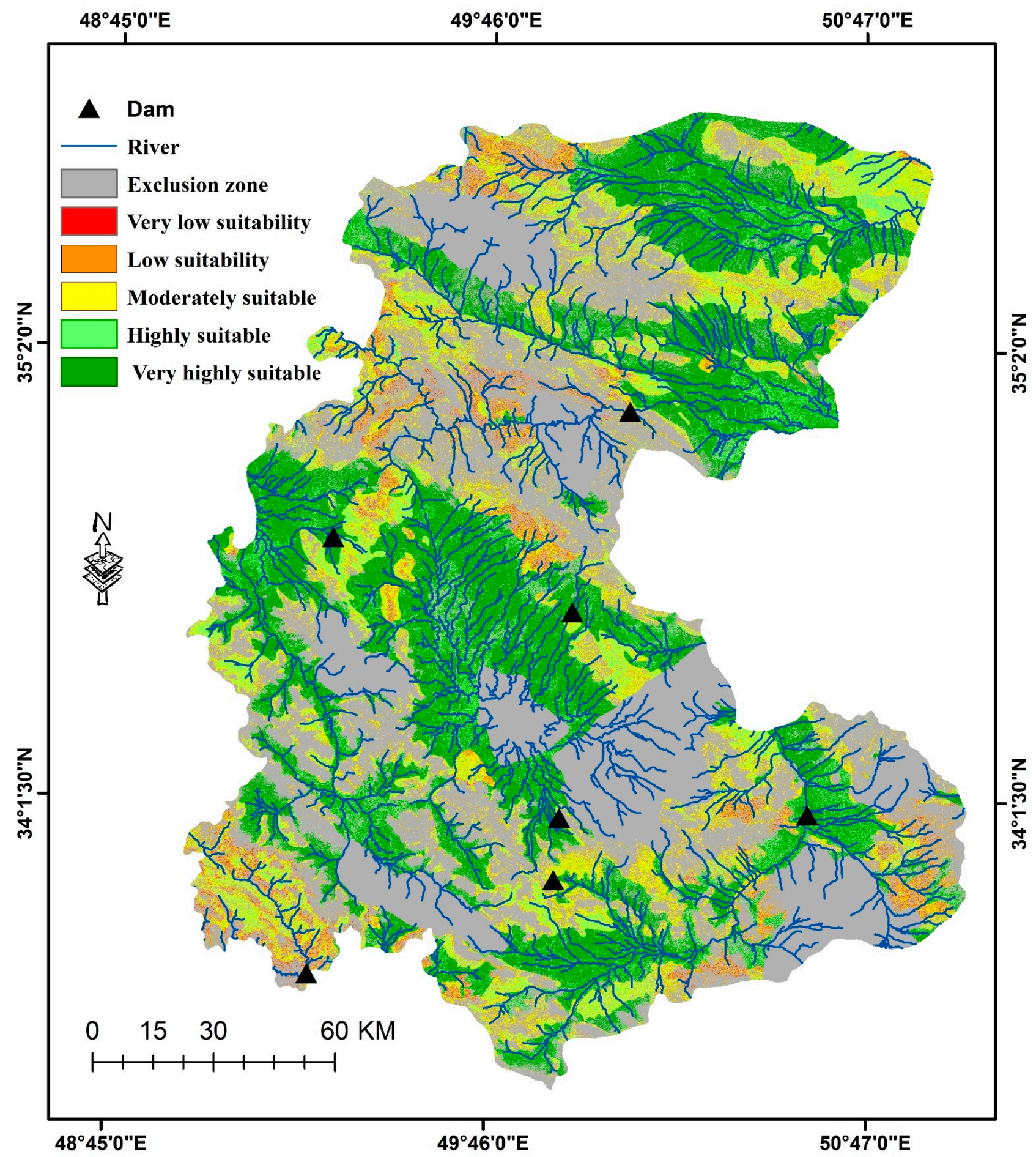

Figure 7. Land potential for suitable aquaculture development of Oncorhynchus mykiss (rainbow trout) in Markazi province integrated with the limitation map findings.

Table 4 illustrates, in terms of the ecological land capability, that even though $43.8 \%$ of Markazi province is not suitable for aquaculture, $40 \%$ of it is with an economic potential relating to $13.84 \%$ as highly suitable and $26.95 \%$ as very highly suitable. The results indicate that key areas with high and very high potential are in the central, south, and northeastern part of the province near a water source. As such, most of the capable areas for aquaculture development are located around reservoir dams and dense branches of the hydrological network of Markazi province. 
Table 4. Classification of land for aquaculture development in Markazi province.

\begin{tabular}{ccc}
\hline Land Potential & Area $\mathbf{( H a )}$ & Area (\%) \\
\hline Exclusion Zone & $1,275,062$ & 43.8 \\
Very low suitability & 19,968 & 0.69 \\
Low suitability & 109,950 & 3.78 \\
Moderately suitable & 320,076 & 10.99 \\
Highly suitable & 402,943 & 13.84 \\
Very highly suitable & 784,656 & 26.95 \\
\hline
\end{tabular}

The results of the sensitivity analysis show that by increasing or decreasing each of the criteria by $10 \%$, the prioritization of the criteria remained the same (Table 5). However, it was found that if only the soil texture and depth criteria increased by $10 \%$, the prioritization of the criteria changed the slope, soil erosion, soil texture and depth, and soil structure-as illustrated in Figure 8. In general, as the criteria increased or decreased, the weight of the criteria changed according to the rate of change relative to that criterion-their priority, as stated, did not change.

Table 5. Sensitivity analysis to check criteria validity using a $\pm 10 \%$ interval.

\begin{tabular}{|c|c|c|c|c|}
\hline Interval & \multicolumn{4}{|c|}{ Criteria } \\
\hline \multirow{10}{*}{ Increase by $10 \%$} & \multicolumn{2}{|l|}{ Slope } & \multicolumn{2}{|l|}{ Soil erosion } \\
\hline & slope & 0.469 & slope & 0.440 \\
\hline & soil erosion & 0.260 & soil erosion & 0.280 \\
\hline & soil structure & 0.142 & soil structure & 0.142 \\
\hline & soil texture and depth & 0.138 & soil texture and depth & 0.138 \\
\hline & \multicolumn{2}{|l|}{ Soil structure } & \multicolumn{2}{|c|}{ Soil texture and depth } \\
\hline & slope & 0.441 & slope & 0.441 \\
\hline & soil erosion & 0.260 & soil erosion & 0.260 \\
\hline & soil structure & 0.160 & soil structure & 0.142 \\
\hline & soil texture and depth & 0.138 & soil texture and depth & 0.156 \\
\hline \multirow{10}{*}{ Decrease by $10 \%$} & \multicolumn{2}{|l|}{ Slope } & \multicolumn{2}{|l|}{ Soil erosion } \\
\hline & slope & 0.440 & slope & 0.452 \\
\hline & soil erosion & 0.269 & soil erosion & 0.260 \\
\hline & soil structure & 0.147 & soil structure & 0.146 \\
\hline & soil texture and depth & 0.143 & soil texture and depth & 0.142 \\
\hline & Soil structure & & \multicolumn{2}{|c|}{ Soil texture and depth } \\
\hline & slope & 0.451 & slope & 0.451 \\
\hline & soil erosion & 0.266 & soil erosion & 0.266 \\
\hline & soil structure & 0.142 & soil structure & 0.146 \\
\hline & soil texture and depth & 0.141 & soil texture and depth & 0.138 \\
\hline
\end{tabular}

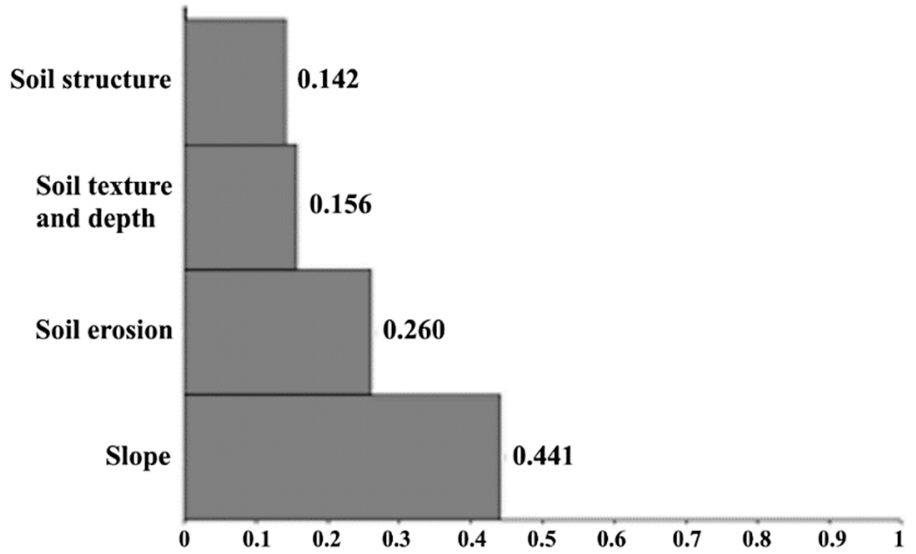

Figure 8. Sensitivity analysis linkage with soil texture and depth. 


\section{Discussion and Conclusions}

The study integrated a GIS-based location selection method with the ANP algorithm to evaluate aquaculture suitability (i.e., land capability) of Oncorhynchus mykiss (rainbow trout). A combined method was used to determine suitable places for aquaculture based on selected conditions. In some situations, it was crucial to use a method that could consider all of the potential characteristics. GIS in combination with ANP applied a sufficient methodological solution to the piecing, together the spatial analysis procedures for the study area. As such, the final output map can assist managers and planners in properly deciding where the most fit location is to develop aquaculture in the province. GIS-based MCDM is a fast and cost-effective method for aquaculture land evaluation purposes, especially in the initial planning stages [75].

A main innovation of the research in comparison with other similar studies can be summarized in two parts. First, this study was conducted in the central parts of the Iranian plateau, where it is very far from the coastline of the north and south of Iran, and, at the same time, it is experiencing climate change issues like other parts of the world, including drought, which can be advantageous as it has created vast opportunities for indigenous people. Second, as mentioned, the research combines GIS and MCDM approaches for a better output, despite the limitations of the data. As such, several studies report the advantages of MCDM methods interfaced with the GIS environment for land evaluation and site selection purposes [54-59]. Given this, recognizing the factors affecting the location and determining the extent of the constraints they create is one of the important issues in valuing aquaculture-prone areas [49]. Therefore, it is essential that researchers in this field in all stages of land evaluation properly review and select these criteria in as much detail as possible. Hence, the location criteria in this study, according to the ecological potential assessment model of the land area for aquaculture [62], using slope, soil texture and depth, soil structure, and soil erosion, proved to be valuable.

To achieve validation of land evaluation and indicators related to aquaculture in Iran, looking at all the studies published to date on the topic, we identified six key papers $[15,33,54,69,76,77]$. All these studies showed similar climatic and geographical specifications in which the most practical indicators in relation to sustainable aquaculture were slope, soil structure, and soil texture and depth. Moreover, in-line with our study, almost in all of them sourced the importance of these parameters in a similar weighing order to this paper. In addition, according to the Statistical Center of Iran [78], among the counties in Markazi province, Arak (i.e., 31 pools), Saveh (i.e., 18 pools), Tafresh (i.e., 15 pools), and Khomain (i.e., 15 pools) are at the top in terms of aquaculture producing areas province-wide. These counties and pool totals correspond with the 96 hectares of total area of aquaculture in Markazi province, which also highlights another correlation with the results of the study.

Examination of the criteria set using GIS and ANP showed that $43.8 \%$ of the studied lands in Markazi province did not have the potential for aquaculture, and nearly $40.79 \%$ of them were highly and extremely suitable. This positions the province as very favorable for aquaculture development-especially in the central, south, and northeastern regions in close proximity to the hydrological network. The study showed that a combination of GIS with the applied ANP model can be used effectively in land assessment for aquaculture development. At length, two study-specific points should be considered in aquaculture land evaluation. First, water quality (e.g., DO, NH3, No3-1, No2-1, pH, and temperature) is not very important in terms of aquaculture land evaluation in Iran, as this is an internal governmental factor and such parameters are controlled and adjusted for prior to any site implementation. Second, increasing land evaluation parameters can improve the accuracy of the location selection, e.g., by increasing the layers and data. As such, this will always be an obstacle when conducting land capability assessments that require large-scale government investment to create or expand current facilities.

It should be noted that Iran is divided into five broad geographical regions in terms of vegetation and climate. The Irano-Turanian region, which covers about $28 \%$ of Iran, is where 
the study area is located. With very similar climate and geomorphology, a generalization of the results can be implied for the greater part of this region. Nonetheless, this study is still heavily reliant on the availability of information and data, as this is reserved for the provincial level in the country. From this research, it should also be stressed that Markazi province is one of the most attractive provinces in Iran in terms of investment, due to its proximity to the capital-Tehran-and other large cities such as Isfahan and Qom. As the province acts as a western corridor, which that connects the center of the country to its western parts and neighboring countries, the relatively favorable environmental conditions and industrial nature of the province, i.e., compared to other parts of the country, show promise for many parent industries-including aquaculture. To alleviate and reverse any further negative development from poor planning and management, this study comprehensively considered Markazi province and deduced the option (and challenge) of integrating inland aquaculture into the province's production sector as partially feasible. In this case, the use of inland aquaculture is a problem-solution-resolution type of approach. It is stressed as an advancement to the sustainable development agenda of the country, an asset for local and healthy food (i.e., dietary daily protein intake), and a growth potential for exportation and the economy.

Overall, Markazi province has the potential to develop inland aquaculture facilities and become a key seafood producer in the region. However, a sensible understanding needs to be taken into consideration, as the gap over the last few decades of unplanned growth and development disruptions after the Islamic Revolution and the Iraq war, and considering how these geopolitical problems have stalled development, should be taken into account. Future work, through comprehensive and realistic data analyses, should introduce potential aquaculture development, while still considering (i.e., reviewing) existing conditions and the prospective for change. It seems that most of the susceptible areas in Markazi province have already been occupied either by residential areas or other human activities, and some of them have been developed inappropriately due to the geography and natural limitations of the province's geography. Through GIS-based MCDM, it is hopeful that future development can be better planned and managed for sound and sustainable practice province-wide.

Supplementary Materials: The following supporting information can be downloaded at https: / / www.mdpi.com/article/10.3390/ijgi11030157/s1. Table S1: Aquaculture land evaluation. Table S2: Comparison and weighting of slope divisions in Markazi province. Table S3: Comparison and weighting of erosion divisions in Markazi province. Table S4: Comparison and weighting of soil texture and depth divisions in Markazi province. Table S5: Comparison and weighting of soil structure divisions in Markazi province.

Author Contributions: Conceptualization: Amir H. Aghmashhadi; software, validation, formal analysis, data curation, and writing-original draft preparation: Amir H. Aghmashhadi, Ali Azizi, Maryam Hoseinkhani, and Samaneh Zahedi; methodology, investigation, resources, and project administration: Amir H. Aghmashhadi, Ali Azizi, Maryam Hoseinkhani, Samaneh Zahedi, and Giuseppe T. Cirella; visualization, supervision, funding acquisition, and writing-review and editing: Giuseppe T. Cirella. All authors have read and agreed to the published version of the manuscript.

Funding: This research was funded by the Markazi province Office of Planning and Budget Organization, grant number 688030. The APC was funded by the Polo Centre of Sustainability.

Institutional Review Board Statement: Not applicable.

Informed Consent Statement: Not applicable.

Data Availability Statement: The data are available from the corresponding author upon reasonable request.

Acknowledgments: The authors are extremely grateful to the Iranian National Cartographic Center, Markazi Province Office of Planning and Budget Organization, Markazi Province Office of Agriculture Organization at Jahad, and the Markazi Province Department of Environment. 
Conflicts of Interest: The authors declare no conflict of interest.

\section{References}

1. Belton, B.; Little, D.C.; Zhang, W.; Edwards, P.; Skladany, M.; Thilsted, S.H. Farming fish in the sea will not nourish the world. Nat. Commun. 2020, 11, 5804. [CrossRef] [PubMed]

2. FAO. Fishery and Aquaculture Statistics; Food and Agriculture Organization of the United Nations: Rome, Italy, 2018.

3. Naylor, R.L.; Hardy, R.W.; Buschmann, A.H.; Bush, S.R.; Cao, L.; Klinger, D.H.; Little, D.C.; Lubchenco, J.; Shumway, S.E.; Troell, M. A 20-year retrospective review of global aquaculture. Nature 2021, 591, 551-563. [CrossRef] [PubMed]

4. Vaz, L.; Sousa, M.C.; Gomez-Gesteira, M.; Dias, J.M. A habitat suitability model for aquaculture site selection: Ria de Aveiro and Rias Baixas. Sci. Total Environ. 2021, 801, 149687. [CrossRef] [PubMed]

5. Charisiadou, S.; Halling, C.; Jiddawi, N.; von Schreeb, K.; Gullström, M.; Larsson, T.; Nordlund, L.M. Coastal aquaculture in Zanzibar. Tanzania. Aquac. 2022, 546, 737331. [CrossRef]

6. Jing, Z.; Ningning, Z.; Zaki, S.; Yong, L.; Jun, M.; Yanan, L. Effects of dietary lipid and protein levels on growth and physiological metabolism of Pelteobagrus fulvidraco larvae under recirculating aquaculture system (RAS). Aquaculture 2018, 495, 458-464.

7. Hossain, M.S.; Das, N.G. GIS-based multi-criteria evaluation to land suitability modelling for giant prawn (Macrobrachium rosenbergii) farming in Companigonj Upazila of Noakhali, Bangladesh. Comput. Electron Agric. 2010, 70, 172-186. [CrossRef]

8. De Novaes Vianna, L.F.; Bonetti Filho, J. Spatial analysis for site selection in marine aquaculture: An ecosystem approach applied to Baía Sul, Santa Catarina, Brazil. Aquaculture 2018, 489, 162-174. [CrossRef]

9. FAO; World Bank. Aquaculture Zoning, Site Selection and Area Management under the Ecosystem Approach to Aquaculture a Handbook; Food and Agriculture Organization of the United Nations: Rome, Italy, 2017.

10. Brugère, C.; Aguilar-Manjarrez, J.; Beveridge, M.C.M.; Soto, D. The ecosystem approach to aquaculture 10 years on-A critical review and consideration of its future role in blue growth. Rev. Aquac. 2019, 11, 493-514. [CrossRef]

11. Rikalovic, A.; Cosic, I.; Lazarevic, D. GIS Based Multi-Criteria Analysis for Industrial Site Selection. 24th DAAAM International Symposium on Intelligent Manufacturing and Automation, 2013. Procedia Eng. 2014, 69, 1054-1063. [CrossRef]

12. Chao, L.; Yanbing, J.; Ernesto, D.R.S.G.; Peiwu, D.; Aihua, W. The waste-to-energy incineration plant site selection based on hesitant fuzzy linguistic Best-Worst method ANP and double parameters TOPSIS approach: A case study in China. Energy 2020, $211,118564$.

13. Li, Y.; Wang, Y.; Gao, X.; Xie, T.; Hai, R.; Zhang, X. Multi-criteria Evaluation Method for Site Selection of Industrial Wastewater Discharge in Coastal Regions. J. Clean. Prod. 2017, 161, 1143-1152. [CrossRef]

14. Nayak, A.K.; Pant, D.; Kumar, P.; Mahanta, P.C.; Pandey, N.N. GIS-based aquaculture site suitability study using multi-criteria evaluation approach. Indian J. Fish 2014, 61, 108-112.

15. Ghobadi, M.; Nasri, M.; Ahmadipari, M. Land suitability assessment (LSA) for aquaculture site selection via an integrated GIS-DANP multi-criteria method; a case study of lorestan province, Iran. Aquaculture 2021, 530, 735776. [CrossRef]

16. ESRI. ArcGIS Desktop. Environmental Systems Research Institute Web. 2011. Available online: https://desktop.arcgis.com/en/ arcmap (accessed on 12 June 2020).

17. Nath, S.S.; Bolte, J.P.; Ross, L.G.; Aguilar-Manjarrez, J. Applications of geographical information systems (GIS) for spatial decision support in aquaculture. Aquacult. Eng. 2000, 23, 233-278. [CrossRef]

18. Dapueto, G.; Massa, F.; Costa, S.; Cimoli, L.; Olivari, E.; Chiantore, M.; Federici, B.; Povero, P. A spatial multi-criteria evaluation for site selection of offshore marine fish farm in the Ligurian Sea, Italy. Ocean Coast. Manag. 2015, 116, 64-77. [CrossRef]

19. Yin, S.; Takeshige, A.; Miyake, Y.; Kimura, S. Selection of suitable coastal aquaculture sites using Multi-Criteria Decision Analysis in Menai Strait, UK. Ocean. Coast. Manag. 2018, 165, 268-279. [CrossRef]

20. Kapetsky, J.M.; Aguilar-Manjarrez, J. Geographic Information Systems, remote sensing and mapping for the development and management of marine aquaculture. In Fisheries and Aquaculture Technical Paper 458; FAO: Rome, Italy, 2007.

21. Aguilar-Manjarrez, J.; Kapetsky, J.M.; Soto, D. The potential of spatial planning tools to support the ecosystem approach to aquaculture. FAO/Rome Expert Workshop. 19-21 November 2008, Rome, Italy. In FAO Fisheries and Aquaculture Proceedings; No. 17; FAO: Rome, Italy, 2010; 176p.

22. Meaden, G.J.; Aguilar-Manjarrez, J. (Eds.) Advances in Geographic Information Systems and Remote Sensing for Fisheries and Aquaculture, Summary Version; Food and Agriculture Organization of the United Nations: Rome, Italy, 2013.

23. Ross, L.G.; Mendoza, Q.M.E.A.; Beveridge, M.C.M. The application of geographical information systems to site selection for coastal aquaculture: An example based on salmonid cage culture. Aquaculture 2013, 112, 165-178. [CrossRef]

24. Khamis, A.; Khatib, T.; Yosliza, N.A.H.M.; Azmi, A.N. Optimal selection of renewable energy installation site in remote areas using segmentation and regional technique: A case study of Sarawak, Malaysia. Sustain. Energy Technol. Assess. 2020, $42,100858$. [CrossRef]

25. Malczewski, J. GIS-based land-use suitability analysis: A critical overview. Prog. Plan. 2004, 62, 3-65. [CrossRef]

26. Diaz, H.; Soares, C.G. An integrated GIS approach for site selection of floating offshore wind farms in the Atlantic continental European coastline. Renew. Sustain. Energy Rev. 2020, 134, 110328. [CrossRef]

27. Izadikhah, M.; Saen, R.F. A new preference voting method for sustainable location planning using geographic information system and data envelopment analysis. J. Clean. Prod. 2016, 137, 1347-1367. [CrossRef] 
28. El-Gayar, O.F.; Leung, P.S. A multiple criteria decision-making framework for regional aquaculture development. European J. Oper. Res. 2001, 133, 462-482. [CrossRef]

29. Martinez-Cordero, F.J.; Leung, P.S. Multi-criteria Decision making (MCDM) Model for regional sustainable shrimp farming development in northwest Mexico. Aquac. Econ. Manag. 2004, 8, 179-192. [CrossRef]

30. Hasala, D.; Supak, S.; Rivers, L. Green infrastructure site selection in the Walnut Creek wetland community: A case study from southeast Raleigh, North Carolina. Landsc. Urban Plan. 2020, 196, 103743. [CrossRef]

31. Wiltshire, K.H.; Tanner, J.E. Comparing maximum entropy modelling methods to inform aquaculture site selection for novel seaweed species. Ecol. Model. 2020, 429, 109071. [CrossRef]

32. Venier, C.; Menegon, S.; Possingham, H.P.; Gissi, E.; Zanella, A.; Depellegrin, D.; Sarretta, A.; Barbanti, A.; McGowan, J. Multi-objective zoning for aquaculture and biodiversity. Sci. Total Environ. 2021, 785, 146997. [CrossRef]

33. Hadipour, A.; Vafaie, F.; Hadipour, V. Land suitability evaluation for brackish water aquaculture development in coastal area of Hormozgan, Iran. Aquac. Int. 2014, 23, 329-343. [CrossRef]

34. Buitrago, J.; Rada, M.; Hernandez, H.; Buitrago, E. A single-use site selection technique, using GIS, for aquaculture planning, choosing locations for mangrove oyster raft culture in Margarita Island, Venezuela. Environ. Manag. 2005, 35, 544-556. [CrossRef]

35. Silva, C.; Ferreira, J.G.; Bricker, S.B.; Delvalls, T.A.; Martín-Díaz, M.L.; Yañez, E. Site selection for shellfish aquaculture by means of GIS and farm-scale models, with an emphasis on data-poor environments. Aquaculture 2011, 318, 444-457. [CrossRef]

36. Radiarta, I.N.; Saitoh, S.I.; Miyazono, A. GIS-based multi-criteria evaluation models for identifying suitable sites for Japanese scallop (Mizuhopecten yessoensis) aquaculture in Funka Bay, southwestern Hokkaido, Japan. Aquaculture 2008, 284, 127-135. [CrossRef]

37. Micael, J.; Costa, A.C.; Aguiar, P.; Medeiros, A.; Calado, H. Geographic information system in a multi-criteria tool for mariculture site selection. Coast Manag. 2015, 43, 52-66. [CrossRef]

38. Liu, Y.; Saitoh, S.-I.; Radiarta, I.N.; Isada, T.; Hirawake, T.; Mizuta, H.; Yasui, H. Improvement of an aquaculture site-selection model for Japanese kelp (Saccharina japonica) in southern Hokkaido, Japan: An application for the impacts of climate events. ICES J. Mar. Sci. 2013, 70, 1460-1470. [CrossRef]

39. Aguilar-Manjarrez, J.; Ross, L.G. Geographical information systems (GIS), environmental models for aquaculture development in Sinaloa state, Mexico. Aquac. Int. 1995, 3, 103-115. [CrossRef]

40. Arnold, W.S.; White, M.W.; Norris, H.A.; Berrigan, M.E. Hard clam (Mercenaria spp.) aquaculture in Florida, USA: Geographic information system applications to lease site selection. Aquac. Eng. 2000, 23, 203-231. [CrossRef]

41. Calle Yunis, C.R.; Salas López, R.; Cruz, S.M.O.; Barboza Castillo, E.; Silva López, J.O.; Iliquín Trigoso, D.; Briceño, N.B.R. Land Suitability for Sustainable Aquaculture of Rainbow Trout (Oncorhynchus mykiss) in Molinopampa (Peru) Based on RS, GIS, and AHP. ISPRS Int. J. Geo-Inf. 2020, 9, 28. [CrossRef]

42. Karthik, M.; Suri, J.; Saharan, N.; Biradar, R.S. Brackish water aquaculture site selection in Palghar Taluk, Thane district of Maharashtra, India, using the techniques of remote sensing and geographical information system. Aquac. Eng. 2005, 32, 285-302. [CrossRef]

43. Mcleod, I.; Pantus, F; Preston, N. The use of a geographical information system for land-based aquaculture planning. Aquac. Res. 2002, 33, 241-250. [CrossRef]

44. Giap, D.H.; Yi, Y.; Yakupitiyage, A. GIS for land evaluation for shrimp farming in Haiphong of Vietnam. Ocean Coast Manag. 2005, 48, 51-63. [CrossRef]

45. Perez, O.M.; Telfer, T.; Glenn Ross, L. Use of GIS-Based Models for Integrating and Developing Marine Fish Cages within the Tourism Industry in Tenerife (Canary Islands). J. Coast. Manag. 2003, 31, 355-366. [CrossRef]

46. Perez, O.M.; Telfer, T.; Glenn Ross, L. Geographical information systems-based models for offshore floating marine fish cage aquaculture site selection in Tenerife, Canary Islands. Aquac. Res. 2005, 36, 946-961. [CrossRef]

47. Radiarta, I.N.; Saitoh, S.I. Biophysical models for Japanese scallop, Mizuhopecten yessoensis, aquaculture site selection in Funka Bay, Hokkaido, Japan, using remotely sensed data and geographic information system. Aquac. Int. 2009, 17, 403-419. [CrossRef]

48. Salam, M.A.; Lindsay, G.R.; Beveridge, M.C.M. A comparison of development opportunities for crab and shrimp aquaculture in south-western Bangladesh, using GIS modeling. Aquaculture 2003, 220, 477-494. [CrossRef]

49. Hossain, M.S.; Chowdhury, S.R.; Das, N.G.; Sharifuzzaman, S.M.; Sultana, A. Integration of GIS and multicriteria decision analysis for urban aquaculture development in Bangladesh. Landsc. Urban Plan 2009, 90, 119-133. [CrossRef]

50. Hossain, M.S.; Chowdhury, S.R.; Das, N.G.; Rahaman, M.M. Multi criteria evaluation approach to GIS-based land suitability classification for tilapia farming in Bangladesh. Aquac. Int. 2007, 15, 425-443. [CrossRef]

51. Assefa, W.W.; Abebe, W.B. GIS modeling of potentially suitable sites for aquaculture development in the lake tana basin, Northwest Ethiopia. Agric. Food Secur. 2018, 7, 72. [CrossRef]

52. Nayak, A.K.; Kumar, P.; Pant, D.; Mohanty, R.K. Land suitability modelling for enhancing fishery resource development in central Himalayas (India) using GIS and multi-criteria evaluation approach. Aquac. Eng. 2018, 83, 120-129. [CrossRef]

53. Esmaeilpour-Poodeh, S.; Ghorbani, R.; Hosseini, S.A.; Salmanmahiny, A.; Rezaei, H.; Kamyab, H. A multi-criteria evaluation method for sturgeon farming site selection in the southern coasts of the Caspian Sea. Aquaculture 2019, 513, 734416. [CrossRef]

54. Vafaie, F.; Hadipour, A.; Hadipour, V. GIS-based fuzzy multi-criteria decision-making model for coastal aquaculture site selection. Environ. Eng. Manag. J. 2012, 14, 2415-2425. [CrossRef] 
55. Mousavi, S.H.; Danehkar, A.; Shokri, M.R.; Poorbagher, H.; Azhdari, D. Site selection for artificial reefs using a new combine multi-criteria decision-making (MCDM) tool for coral reefs in the kish island-Persian Gulf. Ocean Coast Manag. 2015, 111, 92-102. [CrossRef]

56. Mahalakshmi, P.; Panigrahi, A.; Ravisankar, T.; Kumar, J.A.; Shanthi, B. Multi criteria decision making for identification of optimal location for aquaculture development. Int. J. Adv. Sci. Eng. Technol. 2014, 2, 11-14.

57. Vergara-Solana, F.; Araneda, M.E.; Ponce-Díaz, G. Opportunities for strengthening aquaculture industry through multicriteria decision-making. Rev. Aquac. 2019, 11, 105-118. [CrossRef]

58. Villacreses, G.; Gaona, G.; Martínez-Gómez, J.; Jijón, D.J. Wind farms suitability location using geographical information system (GIS), based on multi-criteria decision making (MCDM) methods: The case of continental Ecuador. Renew. Energy 2017, 109, 275-286. [CrossRef]

59. Teniwut, W.A.; Marimin, M.; Djatna, T. GIS-based multi-criteria decision-making model for site selection of seaweed farming information centre: A lesson from small islands, Indonesia. Decis. Sci. Lett. 2019, 8, 137-150. [CrossRef]

60. Markazi Province Meteorological Organization. Climatic Data of Meteorological Station of Markazi Province from 1991 to 2018. 2020. Available online: http:/ / www.markazimet.ir/Index.aspx?tempname=MainEng\&lang=2\&sub=0 (accessed on $10 \mathrm{July} 2020$ ).

61. Google Earth. Google Earth Website. 2022. Available online: https:/ / earth.google.com/web/ (accessed on 15 January 2022).

62. Makhdoum, M.F. Fundamental of Land Use Planning, 15th ed.; University of Tehran Press: Tehran, Iran, 2015.

63. Mehrdad, M.; Oakes, B.J.; Saraoglu, M.; Morozov, A.; Janschek, K.; Denil, J. Exploring Fault Parameter Space Using Reinforcement Learning-based Fault Injection. In Proceedings of the 50th Annual IEEE/IFIP International Conference on Dependable Systems and Networks Workshops (DSN-W), Valencia, Spain, 29 June-2 July 2020. [CrossRef]

64. Aghmashhadi, A.H.; Azizi, A.; Hoseinkhani, M.; Zahedi, S.; Cirella, G.T. Industrial park land capability assessment and post evaluation in Markazi province. Appl. Geomat. 2021. [CrossRef]

65. Malmir, M.; Kheirkhah Zarkesh, M.; Monavari, S. Analysis of land suitability for urban development in Ahwaz County in southwestern Iran using fuzzy logic and analytic network process (ANP). Environ. Monit. Assess. 2016, 188, 1-23. [CrossRef] [PubMed]

66. Seyedmohammadi, J.; Sarmadian, F.; Jafarzadeh, A.A.; McDowell, R.W. Integration of ANP and Fuzzy set techniques for land suitability assessment based on remote sensing and GIS for irrigated maize cultivation. Arch. Agron. Soil Sci. 2019, 65, 1063-1079. [CrossRef]

67. Aragonés-Beltrán, P.; Chaparro-González, F.; Pastor-Ferrando, J.P.; Rodríguez-Pozo, F. An ANP-based approach for the selection of photovoltaic solar power plant investment projects. Renew. Sustain. Energy Rev. 2010, 14, 249-264. [CrossRef]

68. Kuei-Lun, C.; Sen-Kuei, L.; Tzeng-Wei, T.; Chi-Yi, L. An ANP based TOPSIS approach for Taiwanese service apartment location selection. Asia Pac. Manag. Rev. 2015, 20, 49-55.

69. Zarei, M.; Fatemi, M.R.; Mortazavi, M.S.; Pouebrahim, S.; Ghoddousi, J. Selection of the optimal tourism site using the ANP and fuzzy TOPSIS in the framework of Integrated Coastal Zone Management: A case of Qeshm Island. Ocean. Coast. Manag. 2016, 130, 179-187.

70. Arsic, S.; Nikolic, D.; Zivkovic, Z. Hybrid SWOT_ANP_FANP model for prioritization strategies of sustainable development of ecotourism in National Park Djerdap, Serbia. For. Policy Econ. 2017, 80, 11-26. [CrossRef]

71. Yunna, W.; Buyuan, Z.; Chuanbo, X.; Lingwenying, L. Site selection decision framework using fuzzy ANP-VIKOR for large commercial rooftop PV system based on sustainability perspective. Sustain. Cities Soc. 2018, 40, 454-470.

72. Saaty, T.L. Decision Making with Dependence and Feedback: The Analytic Network Process: The Organization and Prioritization of Complexity; RWS Publications: Pittsburgh, PA, USA, 1996.

73. Saaty, T.L. The Analytic Network Process. Decision Making with the Analytic Network Process: Economic, Political, Social and Technological Applications with Benefits, Opportunities, Costs and Risks; Saaty, T.L., Vargas, L.G., Eds.; Springer: New York, NY, USA, 2006; pp. 1-26.

74. Department of Environment. Rules and Regulations for the Establishment of Production, Industrial and Mining Units; Office of Environmental Assessment, Deputy of Human Environment, Iranian Department of Environment: Tehran, Iran, 2019.

75. Ramadhini, M.; Sihombing, A.R. Utilization of Geographic Information System (GIS) in Determining the Suitability of Fisheries Locations Cultivation of Freshwater Fishponds in South Aceh Regency. J. Inotera 2018, 3, 81. [CrossRef]

76. Hemmatyar, A.H.; Asad, A.; Kalantari, K.H. Sustainability Study of Groundwater Sources for Rainbow Trout Farming in Sardasht County, Using Geographic Information Systems (GIS) and Multi-Criteria Decision Making (MCDM). Research 2011, 2, 1-5.

77. Gholifar, E.; Abbasi, E.; Pezeshki Rad, G.; Salehi, H.; Rezaei, A. Development and Validation of Sustainable Aquaculture Indicators: Case of Alborz Dam Basin, Mazandaran, Iran. Int. J. Agric. Manag. Dev. (IJAMAD) 2016, 7, 191-199.

78. Statistical Center of Iran. Markazi Province Statistical Yearbook; Iran Data Portal: Tehran, Iran, 2015. 